\title{
Stand Structure, Diversity and Regeneration Status of Woody Species in Open and Exclosed Dry Woodland Sites around Molapo Farming Areas of the Okavango Delta, Northeastern Botswana
}

\author{
John Neelo1, Demel Teketay ${ }^{2}$, Keotshephile Kashe1, Wellington Masamba1 \\ ${ }^{1}$ Okavango Research Institute, University of Botswana, Maun, Botswana \\ ${ }^{2}$ Department of Crop Science and Production, Botswana College of Agriculture, Gaborone, Botswana \\ Email: "dteketay@yahoo.com
}

Received 20 February 2015; accepted 14 March 2015; published 20 March 2015

Copyright (C) 2015 by authors and Scientific Research Publishing Inc.

This work is licensed under the Creative Commons Attribution International License (CC BY). http://creativecommons.org/licenses/by/4.0/

(c) (i)

Open Access

\section{Abstract}

Stand structure, diversity and regeneration status of woody species were investigated in open and exclosed dry woodland sites in Island Safari, Shorobe and Xobe, northeastern Botswana. A total of 105, 111 and 130 quadrats, measuring $20 \times 20 \mathrm{~m}$ each, were laid down along parallel line transects in the three sites, respectively, to collect data. A total of 47 species, representing 16 families and 24 genera, were recorded in the study sites. Of these, 33 species representing 13 families and 20 genera, 41 species representing 15 families and 23 genera and 27 species representing 10 families and 14 genera were encountered in Island Safari, Shorobe and Xobe, respectively. The most diverse family was Fabaceae followed by Combretaceae and Tiliaceae at all the three sites. The most diverse genus was Acacia, followed by Combretum and Grewia. The diversity of woody species in the study sites were 2.18, 2.15 and 1.5 in Shorobe, Island Safari and Xobe, respectively, while their corresponding evenness values were $0.6,0.6$ and 0.5 , respectively. The mean densities of the woody species encountered in Island Safari, Shorobe and Xobe were 2629, 4271 and 2745 individuals ha $^{-1}$, respectively. The five densest species were Colophospermum mopane, Dichrostachys cinerea, Acacia tortilis, Philenoptera violacea and Terminalia prunioides in Island Safari, $C$. mopane, A. tortilis, A. erioloba, $P$. violacea and $D$. cinerea in Shorobe and Acacia mellifera, A. tortilis, $P$. nelsii, $A$. luederitzii and $A$. erubescens in Xobe. The highest important value index values were exhibited by $C$. mopane, D. cinerea, A. tortilis, $P$. violacea and $T$. prunioides in Island Safari, $C$. mopane, $A$. erioloba, $A$. tortilis, $P$. violacea and $C$. imberbe in Shorobe, and A. mellifera, $A$. tortilis, $P$. nel-

\footnotetext{
${ }^{*}$ Corresponding author.
}

How to cite this paper: Neelo, J., Teketay, D., Kashe, K., \& Masamba, W. (2015). Stand Structure, Diversity and Regeneration Status of Woody Species in Open and Exclosed Dry Woodland Sites around Molapo Farming Areas of the Okavango Delta, Northeastern Botswana. Open Journal of Forestry, 5, 313-328. http://dx.doi.org/10.4236/ojf.2015.54027 
sii and $A$. luederitzii in Xobe. The alarming result was the fact that $71 \%, 80 \%$ and $85 \%$ of the woody species recorded in Island Safari, Shorobe and Xobe, respectively, exhibited hampered regeneration and, thus, unhealthy population structures. Therefore, there is an urgent need to address the observed unhealthy population structures of the woody species through investigation of the major causes of their hampered regeneration, and also designing measures that will facilitate natural and artificial regeneration of these species at the three study sites.

\title{
Keywords
}

\author{
Anthropogenic Disturbance, Area Exclosure, Deforestation, Density, Diversity, Flood Recession \\ (Molapo) Farming, Important Value Index, Population Structure, Regeneration
}

\section{Introduction}

Tropical forests, which are home to around half of the terrestrial plant and animal species, are being destroyed at rates unprecedented in geological history (WCMC, 1992; Wright \& Muller-Landau, 2006; LaFrankie et al., 2006; Lu et al., 2010; Elliot et al., 2013). The result is a wave of species extinctions that is leaving our planet both biologically impoverished and ecologically less stable. Since pre-industrial times, tropical forests have shrunk in area by 35\% - 50\% (Wright \& Muller-Landau, 2006; Elliot et al., 2013). The degradation of dry forests and habitat loss due to anthropogenic activities are among the major causes of decline in biodiversity (Pickett \& White, 1985). To meet the increasing demands of rapidly increasing human population, natural forest resources are being utilized far beyond their regenerative capacity. This has resulted in decreasing size and quality of natural forests at alarming rates in Africa and other parts of the world. The effect of human disturbances on species diversity is an issue that has engaged ecologist since long (Pickett \& White, 1985; Tilman, 1988; Vetaas, 1997; Sheil, 1999; Wright \& Muller-Landau, 2006; Lawes et al., 2007; Sapkota et al., 2009; Lu et al., 2010).

For the management of both undisturbed and disturbed forest communities, it is very important to understand forest stand structure and composition (Congdon \& Herbohn, 1993; Ssegawa \& Nkuutu, 2006). Such an understanding helps the forest managers to assess the potential impacts, the amelioration of effects of disturbance, optimization of productivity and rehabilitation of degraded ecosystems (Congdon \& Herbohn, 1993). Assessment of floristic composition and structure of forest communities is also useful in identifying important elements of plant diversity, protecting threatened and economic species, and monitoring the forest communities, among others (Tilman, 1988; Ssegawa \& Nkuutu, 2006). The status of tree populations can be revealed by way of size class distribution analyses (Newbery \& Gartlan, 1996; Condit et al., 1998). For natural populations with good and continuous rejuvenation, size class distributions are generally exponentially decaying with many more trees in smaller size classes than in larger ones (Hall \& Bawa, 1993). With certain reservations, a lack of juveniles can, therefore, be an indication of declining populations. On the other hand, size class distribution analyses can indicate trends in species for the nearest future.

Historically, human disturbance has been in existence in dry forests and dates back to early human occupation of forest regions (Fairhead \& Leach, 1998). Disturbances of both natural and human origin influence forest dynamics and tree diversity at local and regional scales (Sheil, 1999; Sapkota et al., 2009), and do not only influence diversity, but also post-disturbance regeneration and dominance of tree species (Lawes et al., 2007). Several studies (Vetaas, 1997; Sheil, 1999; Venkateswaran \& Parthasarathy, 2003; Lawes et al., 2007) have explained the relationship between disturbance and species richness, but the studies that elucidate how disturbances influence stand structure, species composition and regeneration of tree species are very limited (Sapkota et al., 2009), and this is also the case in Botswana. Woody vegetation has received little attention in management strategies (von Maydell, 1995), although it is well documented that woody species are both essential for sustaining the livelihoods of local people (von Maydell, 1986). Woody species play critical roles in providing goods and services necessary for the well-being of both humans and animals. For instance, they serve as sources of food, beverages, animal feed, timber/wood used for various purposes, fuel wood, charcoal, medicine, honey, spices, gums and resins, other non-timber forest/woodland products, tourism, etc. They have also cultural and spiritual as well 
as environmental importance. They play significant roles in carbon sequestration-mitigation of climate change, soil and water conservation, watershed protection, nutrient recycling, nitrogen fixation, amenity and recreation, creation of microclimate, gene conservation, and as habitat and breeding ground for different organisms. Despite this reality, they are severely affected by degradation processes (GEMS, 1988; Holmes, 2003). Therefore, there is an urgent need for their restoration, proper management, sustainable utilization and conservation, which, in turn, require a good understanding of their stand structures as well as diversity and status of regeneration of woody species.

Dry forests and woodlands in northwestern Botswana are among the biodiversity rich regions of southern Africa. However, this is the part of the country where flood recession farming has been excessively practiced. Flood recession farming is an important livelihood activity that depends on natural (flood) waters. It makes use of fields that are located close to or in the floodplain or river channel where soils are moistened by seasonal flooding and supplemented by rainfall (Chimbari et al., 2009; Neelo et al., 2013). During the recession of the floods, the fields gradually dry up, and strips parallel to the remaining water can be successively planted. This type of practice has huge implications on the surrounding vegetation as most people practicing it are usually subsistence farmers who lack financial muscles to buy materials to fence their fields and construct their homes and, as such, relying on the vegetation for provision of materials for these purposes. So, the resources are now under increasing anthropogenic pressure, such as timber extraction, firewood collection, cattle grazing, etc. (Neelo et al., 2013).

In spite of the increasing human activities in the woodlands, few studies have been conducted to assess their impacts on plant assemblages in the area. Past studies in other countries have indicated that due to disturbance in the forests, condition shave become unfavorable for existing species, which, as a result, fail to reestablish themselves (Singh \& Singh, 1992). One of the cheapest and convenient methods employed to restore, manage and conserve woody species is the establishment of area exclosures (also referred to as area enclosures or enclosures) (Birhane et al., 2004, 2006; Mengistu et al., 2005a, b; Hailu et al., 2006; Mekuria et al., 2007; Teketay et al., 2010). Area exclosure is the practice of land management that involves the exclusion of livestock and humans from openly accessing an area that is characterized by severe degradation (Aerts et al., 2009; Teketay et al., 2010). The purposes of exclusion of animals and humans are to prevent further degradation of the ecosystems advance revegetation/forest regeneration and restore the overall ecological conditions of the areas. In area exclosures, restoration/rehabilitation is primarily a natural process and human inputs are limited to offering protection against interferences. For this reason, some call it "zero management” strategy for rehabilitation. The zero management makes it also the cheapest method of rehabilitation of degraded areas. Nonetheless, in few cases, exclosures are supplemented with enrichment plantings of native and/or exotic species as well as soil and water conservation activities to speed up the restoration processes.

In this study, we have set out to undertake a comparative investigation on the woody plant diversity (species richness, diversity and evenness), stand structure of the woodlands (density, abundance, frequency, dominance/ basal area, population structure and important value index) and regeneration status of the woody species of a site, which has been enclosed for more than 30 years, and two nearby sites, which have been exposed to anthropogenic disturbances, including grazing of domestic animals. We hypothesized that long years of exclosure prevents further degradation, thereby, enhancing the various stand structures in a given area containing woody vegetation. The specific objectives of the study were to: 1) investigate the species richness, diversity and evenness of woody species; 2) assess similarities in floristic composition of woody species among the three study sites; 3 ) determine the density, frequency and dominance and important value indices; and 4) assess the population structure and regeneration status of woody species in the study sites.

\subsection{Study Sites}

The study was carried out in Island Safari Lodge located in Maun (hereafter referred to as Island Safari) at $19^{\circ} 59^{\prime} 0^{\prime \prime}$ South, $23^{\circ} 25^{\prime} 0^{\prime \prime}$ East, Shorobe Village (hereafter referred to as Shorobe) and Xobe Village (hereafter referred to as Xobe) in northeastern Botswana (Figure 1). Owing to the lack of sites with woody vegetation resources that have not been hampered by humans and domestic animals in the study area, Island Safari was selected as a proxy (control) site to intact woody vegetation resource since it has been exclosed from human and domestic animal interference for more than 30 years. The other two villages, namely Shorobe and Xobe, have been identified as suitable sites since they have different flooding patterns and local topography and, conse- 


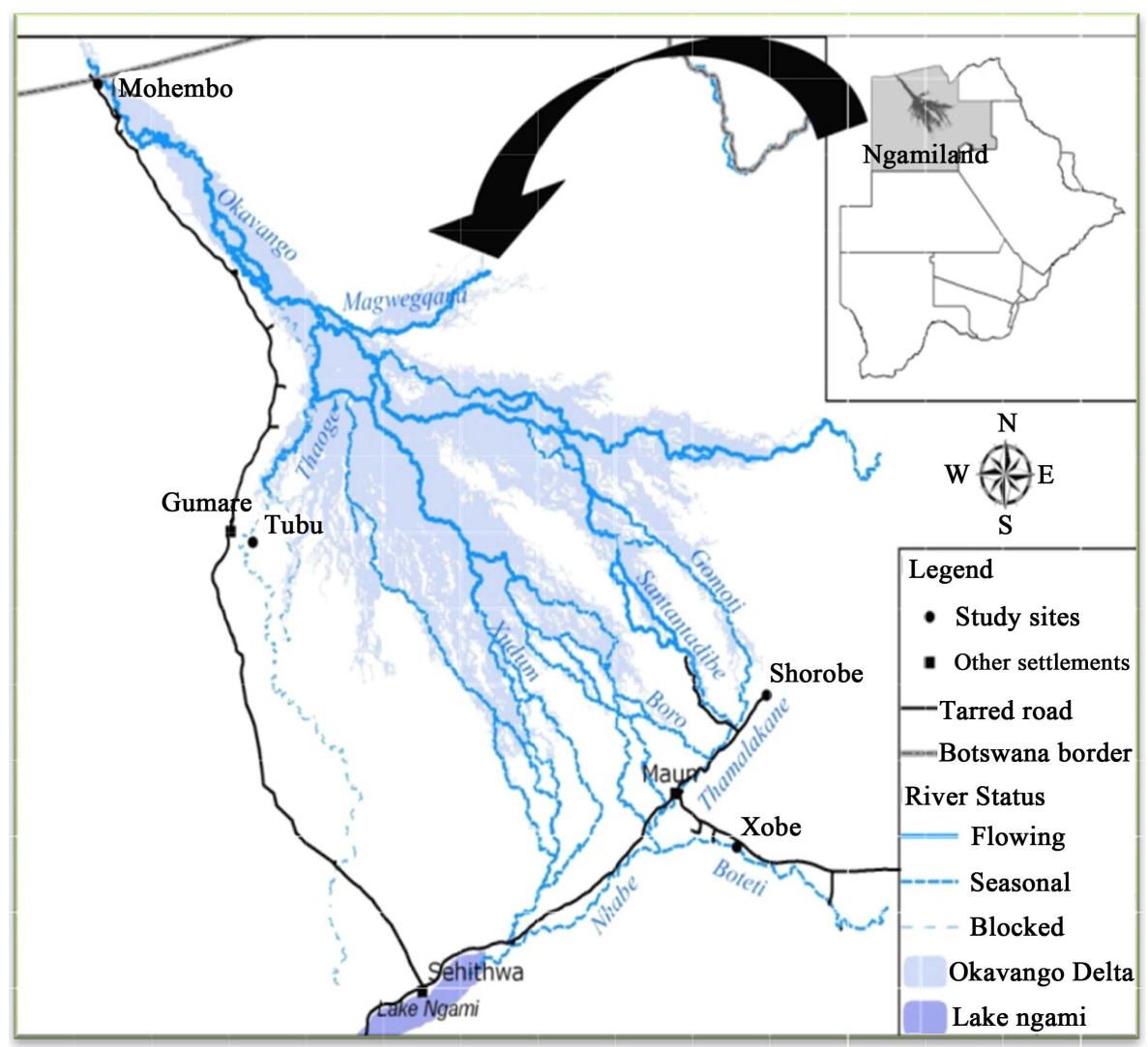

Figure 1. Map showing location of the study sites (Chimbari et al., 2009).

quently, variations in molapo farming practices (Chimbari et al., 2009; Neelo et al., 2013). The three sites fall within the Okavango Delta, part of the wetland system, which starts in the highlands of Angola. The molapofarming system in these areas is dependent upon the rainfall at the source averaging $1400 \mathrm{~mm} \cdot \mathrm{year}^{-1}$ with the Okavango Delta receiving an average of 450 - $500 \mathrm{~mm}_{\text {year }}{ }^{-1}$ (McCarthy et al., 1998; Neelo et al., 2013).

Island Safari, which is strategically located at the edge of the Thamalakane River, originating from the Okavango Delta, is a privately owned property, which has been established in 1972 . The property has been a disturbed open area used for cattle post and molapo farming by the local communities until it was exclosed with a fence in the early 1980s. At the beginning, people could not accept establishment of the exclosure and, hence, were illegally cutting the fence to allow their livestock through and access the river and graze in the land. This continued to create conflicts between the management of Island Safari and the cattle owners until 1986, when an official instruction was issued from the ministry responsible for tourism at that time to ban livestock grazing and molapo farming in the property. Hence, the fence was put up again in the late 1980s and re-enforced with an electric fence in 2006. Despite these efforts, cases of illegal cutting of the fence and woody species, including palm trees for their leaves used in thatching, as well as livestock grazing inside the property were observed. Wild animals, namely kudu, impala and monkeys, inhabit the property. Hence, overgrazing has been a serious problem in Island Safari. Currently, the property, including the vegetation, is protected by two guards. Therefore, grazing by livestock and cutting of woody species has been prevented. However, the property experiences recurrent flooding during the rainy seasons when the volume of water in the Thamalakane River (Okavango Delta) increases.

Shorobe Village is located in Ngamiland East Sub-District about $36 \mathrm{~km}$ northeast of Maun. It lies between $19^{\circ} 45^{\prime} 56.71^{\prime \prime}$ South and $23^{\circ} 40^{\prime} 10.53^{\prime \prime}$ East and has a population of 1031 people (CSO, 2011). To the northwest of the village, there is an extensive network of molapo fields fed by the Santantadibe and Gomoti Rivers and by backflow from the Thamalakane River. Soils in molapo fields are classified as young alluvial soils. Texture varies from clayey (35\% to 60\% clay), especially in low-lying areas, through fine loamy (18\% to $35 \%$ clay) to coarse loamy (<18\% clay) (Chimbari et al., 2009; Neelo et al., 2013). Flooding of most molapo fields has not 
occurred for several years until flood waters returned in 2009. When floods occur, molapo fields are cultivated as the flood recedes. The villagers practise both arable and pastoral farming. The main crops planted are maize, sorghum, millets, pumpkins, water melons, melons, sweet reeds, beans and groundnuts. The local people are also engaged in traditional beer brewing and palm wine making, fishing and basket weaving (Neelo et al., 2013).

Xobe Village, with a population of 418 people (CSO, 2011), is a cattlepost area on the south bank of the Boteti River, about $13 \mathrm{~km}$ east of Maun. The area lies between $20^{\circ} 7^{\prime} 10.26^{\prime \prime}$ South and $23^{\circ} 27^{\prime} 41.26^{\prime \prime}$ East. The river normally floods in July, but in dry years (e.g. in the late 1990s), the flood may not reach the settlement. Soils in Xobe settlement molapo fields are coarse textured alluvial deposits (Chimbari et al., 2009; Neelo et al., 2013). Livelihood activities for people in Xobe settlement include rain-fed farming, molapo farming, irrigated vegetable production and livestock rearing. Molapo farmers cultivate along the river banks as the water flow recedes. Ploughing is done using donkeys, though smaller areas may be cultivated with hand hoes. The main crops planted are maize, pumpkins, sweet sorghum and gourds. Other activities include harvesting of wild plants for sale and fishing (Neelo et al., 2013).

The vegetation in Island Safari is dominated by Colophospermum mopane (Kirk ex Benth.) Kirk ex Leonard, Dichrostachys cinerea (L.) Wight \& Arn., Acacia tortilis (Forssk.) Hayne, Philenoptera violacea (Klotzsch) Schrire and Terminalia prunioides M. A. Lawson. The vegetation in Shorobe is dominated by C. mopane, A. tortilis, Acacia erioloba E. Mey. and P. violacea. In Xobe the vegetation is dominated by A.tortilis and Acacia mellifera (Vahl) Benth., Philenoptera nelsii (Schinz) Schrire and Acacia luederitzii Engl. (Neelo et al., 2013).

\subsection{Methods}

The three study sites described above were used to assess woody plant diversity (species richness, diversity and evenness), stand structure of the woodlands (density, abundance, frequency, dominance/basal area, population structure and important value index) and regeneration status of the woody species. Since there are no molapo farms in Island Safari, the vegetation was stratified into three based on the abundance of woody individuals as dense, medium dense and sparsely dense stands and their area coverage. In the dense stands, 45 quadrats each measuring $20 \times 20 \mathrm{~m}$ were laid down at every $50 \mathrm{~m}$ intervals along three parallel line transects. In each of the medium and sparsely dense stands, 30 quadrats each measuring $20 \times 20 \mathrm{~m}$ were laid down at every $50 \mathrm{~m}$ intervals along two parallel line transects. At Shorobe and Xobe, three molapo fields, at least one kilometer apart, and having adjacent vegetation were randomly selected for the study (Neelo et al., 2013). In each molapo field, $20 \times 20 \mathrm{~m}$ quadrats were laid down at every 50 meters interval along three parallel line transects, which were 50 meters apart. A total of 105, 111 and 130 quadrats representing total areas of 4.2, 4.44 and 5.2 ha were sampled. The number of quadrats in the three study sites varied because of unavailability of additional areas appropriate for the surveys.

In each of the quadrats, the following parameters were recorded: identity of all woody species (WS), number of live individuals of all WS and diameter at breast height (DBH) of all WS (with DBH $>2 \mathrm{~cm}$ ), except juveniles (seedlings and coppices: height $<1.5 \mathrm{~m}$ ). In the case of seedlings and coppices, the number of individuals of each species was counted and recorded in each quadrat. A calliper and graduated measuring stick were used to measure diameter at breath height (DBH) and height of the woody plants and seedlings/coppices, respectively.

The woody species were identified directly in the field by using the available literature (Timberlake, 1980; Ellery \& Ellery, 1997; van Wyk \& van Wyk, 1997, 2007; Heath \& Heath, 2010; Roodt, 1993, 1998; Setshogo, 2002, 2005; Setshogo \& Venter, 2003) and with the help of local people familiar with the flora. Plant nomenclature used in this article follows that of Setshogo and Venter (2003) and Setshogo (2005).

\subsection{Data Analyses}

The data anlyses followed the procedures described in detail by Neelo et al. (2013).

Species richness was determined from the total number of woody species recorded in each of the three study sites. Similarity in the woody species composition among the three study sites was analysed using Jaccard's Similarity Coefficient (Krebs, 1989). The diversity of woody species in each of the three study sites was analysed by using the Shannon Diversity Index (Krebs, 1989; Magurran, 2004). The index takes into account the species richness and proportion of each species in all sampled quadrats of each study site. Evenness or equitability, a measure of similarity of the abundances of the different woody species in the study sites, was analysed by 
using Shannon’s Evenness or Equitability Index (Krebs, 1989; Magurran, 2004). Equitability assumes a value between 0 and 1 , with 1 being complete evenness.

Density of the woody species was calculated by converting the total number of individuals of each woody species encountered in all the quadrats and all transects used in each of the three sites to equivalent number per hectare. The frequency was calculated as the proportion (\%) of the number of quadrats in which each woody species was recorded from the total number of quadrats in each of the sites. Dominance of the woody species, with diameter at breast height $(\mathrm{DBH})$ of $>2 \mathrm{~cm}$, was determined from the space occupied by a species, usually its basal area. The total basal area of each woody species was converted to equivalent basal area per hectare (Kent \& Coker, 1992).

Important value index (IVI), which indicates the relative ecological importance of a given woody species at a particular site (Kent \& Coker 1992), was determined from the summation of the relative values of density, frequency and dominance of each woody species. Relative density was calculated as the percentage of the density of each species divided by the total stem number of all species ha $^{-1}$. Relative frequency of a species was computed as the ratio of the frequency of the species to the sum total of the frequency of all species at each study site. Relative dominance was calculated as the percentage of the total basal area of a species out of the total basal areas of all species at each study site.

The population structure of each of the woody species in each of the three study sites was assessed through histograms constructed by using the density of individuals of each species (Y-axis) categorized into ten diameters classes (X-axis) (Peters, 1996), i.e. $1=<2 \mathrm{~cm} ; 2=2-5 \mathrm{~cm} ; 3=5-10 \mathrm{~cm} ; 4=10-15 \mathrm{~cm} ; 5=15-20 \mathrm{~cm} ; 6=$ $20-25 \mathrm{~cm} ; 7=25-30 \mathrm{~cm} ; 8=30-35 ; 9=35-40 ; 10=>40 \mathrm{~cm}$. Then, based on the profile depicted in the population structures, the regeneration status of each woody species was determined.

\section{Results}

\subsection{Species Richness and Floristic Similarity}

A total of 47 species, representing 16 families and 24 genera, were recorded in the three study sites. Of these, 33 species representing 13 families and 20 genera, 41 species representing 15 families and 23 genera, and 27 species representing 10 families and 14 genera were encountered in Island Safari, Shorobe and Xobe, respectively (Table 1). Only three species, one each from the three sites, were not identified. Shorobe exhibited the highest numbers of families, genera and species than Island Safari, which, in turn, had higher number of families, genera and species than Xobe.

The most diverse family was Fabaceae, with $36 \%$ of the total number of species, followed by Combretaceae (15\%) and Tiliaceae (9\%) at all the three sites (Table 1). All the other families were represented by only one or two species. The highest similarity in family composition was recorded between Island Safari and Shorobe (72\%), and the lowest between Island Safari and Xobe (46\%) (Table 2). Two of the families, namely Bignoniaceae and Burseraceae were exclusively found in Shorobe while Rubiaceae was recorded only in Xobe.

The most diverse genus was Acacia, with 23\% of the total number of species, followed by Combretum (11\%) and Grewia (9\%) (Table 1). All the other genera were represented by only one or two species. The same order holds true when Island Safari and Shorobe are considered while in the case of Xobe, Acacia is followed by Grewia and Combretum. Similar to the family composition, the highest similarity in genus composition was recorded between Island Safari and Shorobe (87\%), and the lowest between Shorobe and Xobe (54\%) (Table 2). Two of the genera, namely Rhigozum and Commiphora were exclusively found in Shorobe while Gardenia was recorded only in Xobe.

The three sites shared 18 of the 47 woody species in common. Similarly, Island Safari shared 31 and 19 of the woody species with Shorobe and Xobe, respectively, while Shorobe shared 22 of the woody species with Xobe (Table 1). Six, four and one of the 47 woody species were recorded exclusively in Shorobe, Xobe and Island Safari, respectively. The highest similarity in species composition was recorded between Island Safari and Shorobe (87\%), and the lowest between Shorobe and Xobe (56\%) (Table 2).

\subsection{Diversity and Evenness}

The diversity values of woody species encountered in the study sites were 2.18, 2.15 and 1.5 in Shorobe, Island Safari and Xobe, respectively, while their corresponding evenness values were 0.6, 0.6 and 0.5, respectively. 
Table 1 . Woody species recorded in the three study sites with their family and local names, mean density (ha ${ }^{-1}$ ), frequency (\%) and dominance $\left(\mathrm{m}^{2} \cdot \mathrm{ha}^{-1}\right)$ values as well as importance value index.

\begin{tabular}{|c|c|c|c|c|c|c|c|c|c|c|c|c|c|c|}
\hline \multirow[t]{2}{*}{ Species } & \multirow[t]{2}{*}{ Family } & \multirow[t]{2}{*}{ Local names } & \multicolumn{3}{|c|}{ Mean Density } & \multicolumn{3}{|c|}{ Mean Frequency } & \multicolumn{3}{|c|}{$\begin{array}{c}\text { Mean } \\
\text { Dominance }\end{array}$} & \multicolumn{3}{|c|}{ IVI } \\
\hline & & & IS & SH & XO & IS & SH & XO & IS & SH & XO & IS & SH & XO \\
\hline Colophospermum mopane & Fabaceae & Mophane & 1000 & 1676 & - & 71 & 40 & - & 28 & 29 & - & 86 & 59 & - \\
\hline Dichrostachys cinerea & Fabaceae & Moselesele & 437 & 218 & 11 & 100 & 59 & 15 & 10 & 1 & 0.1 & 44 & 18 & 4 \\
\hline Acacia tortilis & Fabaceae & Mosu & 360 & 510 & 1068 & 97 & 72 & 70 & 9 & 12 & 50 & 40 & 41 & 90 \\
\hline Philenoptera violacea & Fabaceae & Mopororo & 182 & 257 & 0.4 & 52 & 49 & 2 & 8 & 7 & 0.4 & 25 & 25 & 1 \\
\hline Terminalia prunioides & Combretaceae & Motsiara & 143 & 4 & 36 & 47 & 4 & 21 & 6 & 0.2 & 2 & 20 & 1 & 8 \\
\hline Acacia mellifera & Fabaceae & Mongana & 67 & 70 & 1194 & 14 & 25 & 82 & 0.3 & 0.2 & 33 & 5 & 5 & 90 \\
\hline Grewiaretinervis & Tiliaceae & Mokgomphata & 57 & 88 & 6 & 46 & 39 & 13 & 2.2 & 0.2 & 0.0 & 11 & 9 & 3 \\
\hline Combretum imberbe & Combretaceae & Motswere & 56 & 175 & - & 31 & 41 & - & 2 & 8 & - & 9 & 22 & - \\
\hline Grewia flava & Tiliaceae & Moretlwa & 44 & 88 & 8 & 48 & 34 & 17 & 0.9 & 0.2 & 0.0 & 9 & 7 & 4 \\
\hline Acacia erioloba & Fabaceae & Mogotho & 36 & 477 & 37 & 23 & 82 & 27 & 0.7 & 14 & 5 & 5 & 44 & 11 \\
\hline Ximenia americana & Olacaceae & Moretologa & 26 & 3 & 13 & 30 & 5 & 9 & 0.3 & 0 & 0 & 5 & 1 & 3 \\
\hline Acacia luederitzii & Fabaceae & Mokgwelekgwele & 23 & - & 49 & 18 & - & 28 & 0.3 & - & 11 & 4 & - & 16 \\
\hline Ziziphus mucronata & Rhamnaceae & Mokgalo & 20 & 36 & 1 & 25 & 26 & 2 & 0.2 & 1 & 0.0 & 4 & 6 & 1 \\
\hline Albiziaharveyi & Fabaceae & Molalakgaka & 20 & 2 & - & 11 & 2 & - & 0.2 & 1 & - & 2 & 1 & - \\
\hline Croton megalobotrys & Euphorbiaceae & Motsebe & 16 & 134 & 12 & 15 & 21 & 2 & 0.4 & 5 & 1 & 3 & 14 & 1 \\
\hline Albizia anthelmintica & Fabaceae & Monoga & 16 & 9 & 37 & 9 & 3 & 14 & 0.4 & 0.2 & 3 & 2 & 1 & 6 \\
\hline Diospyros lycoioides & Ebenaceae & Letlhajwa & 16 & 6 & - & 15 & 9 & - & 0.4 & 0 & - & 3 & 1 & - \\
\hline Acacia nilotica & Fabaceae & Motlhabakgosi & 15 & 13 & 1 & 14 & 7 & 1 & 0.4 & 0.2 & 0 & 3 & 2 & 0.3 \\
\hline Grewia bicolor & Tiliaceae & Mogwana & 14 & 175 & 0.2 & 13 & 29 & 1 & 0.1 & 1 & 0.0 & 3 & 12 & 0.2 \\
\hline Rhus tenuinervis & Anacardiaceae & Morupaphiri & 13 & 24 & - & 10 & 19 & - & 0.2 & 0.1 & - & 2 & 4 & - \\
\hline Berchemia discolor & Rhamnaceae & Motsentsela & 11 & 9 & - & 14 & 1 & - & 0.2 & 0.2 & - & 3 & 1 & - \\
\hline Garcinia livingstonei & Clusiaceae & Motsaudi & 11 & 0.3 & - & 11 & 1 & - & 0.3 & 0 & - & 2 & 0.2 & - \\
\hline Gymnosporia senegalensis & Celastraceae & Mothono & 10 & 40 & 36 & 7 & 15 & 21 & 0.3 & 0.2 & 0.3 & 2 & 3 & 6 \\
\hline Acacia hebeclada & Fabaceae & Setshi & 9 & 5 & - & 5 & 1 & - & 0.2 & 0.1 & - & 1 & 0.3 & - \\
\hline Combretum hereroense & Combretaceae & Mokabi & 6 & 33 & 7 & 5 & 19 & 2 & 0.2 & 0.4 & 0.4 & 1 & 4 & 1 \\
\hline Acacia sieberiana & Fabaceae & Moremostlha & 5 & 2 & - & 3 & 3 & - & 0 & 0 & - & 1 & 1 & - \\
\hline Unidentified species & - & Lekwati & 5 & - & - & 4 & - & - & 0 & - & - & 1 & - & - \\
\hline Hyphaene petersiana & Arecaceae & Mokolwane & 3 & 175 & - & 3 & 43 & - & 0 & 0 & - & 1 & 11 & - \\
\hline Mimusops zeyheri & Sapotaceae & Mmupudu & 3 & 2 & 24 & 5 & 1 & 12 & 0 & 0 & 0.2 & 1 & 0.2 & 4 \\
\hline Combretum mossambicense & Combretaceae & Motsweketsane & 2 & 12 & 1 & 2 & 5 & 1 & 0 & 0.1 & 0.0 & 0.3 & 1 & 0.3 \\
\hline Capparis tomentosa & Capparaceae & Motawana & 1 & 2 & - & 2 & 1 & - & 0 & 0.1 & - & 0.3 & 0.3 & - \\
\hline
\end{tabular}




\section{Continued}

\begin{tabular}{|c|c|c|c|c|c|c|c|c|c|c|c|c|c|c|}
\hline Combretum collinum & Combretaceae & Modubana & 1 & 1 & - & 5 & 1 & - & 0 & 0.3 & - & 1 & 0.4 & - \\
\hline Euclea divinorum & Ebenaceae & Motlhakola & 1 & 0.2 & - & 1 & 1 & - & 0 & 0 & - & 0.2 & 0.1 & - \\
\hline Boscia albitrunca & Capparaceae & Motopi & - & 9 & 2 & - & 14 & 6 & - & 1 & 3 & - & 3 & 4 \\
\hline Rhigozum brevispinosum & Bignoniaceae & Lebuta & - & 5 & - & - & 1 & - & - & 0 & - & - & 0.2 & - \\
\hline Commiphora mossambicensis & Burseraceae & Moroka & - & 4 & - & - & 9 & - & - & 0.1 & - & - & 2 & - \\
\hline Grewia flavescens & Tiliaceae & Motsotsojane & - & 3 & - & - & 12 & - & - & 0 & - & - & 1 & - \\
\hline Acacia nigrescens & Fabaceae & Mokoba & - & 2 & - & - & 3 & - & - & 0 & - & - & 0.4 & - \\
\hline Philenoptera nelsii & Fabaceae & Mohatha & - & 2 & 106 & - & 2 & 36 & - & 0 & 22 & & 0.3 & 28 \\
\hline Unidentified species & - & Motorokofina & - & 2 & - & - & 1 & - & - & 0 & - & - & 0.2 & - \\
\hline Acacia fleckii & Fabaceae & Mohahu & - & 0.4 & 1 & - & 1 & 1 & - & 0 & 1 & - & 0.1 & 1 \\
\hline Terminalia sericea & Combretaceae & Mogonono & - & 0.4 & - & - & 2 & - & - & 0 & - & - & 0.3 & - \\
\hline Acacia erubescens & Fabaceae & Moloto & - & 0.2 & 45 & - & 1 & 25 & - & 0 & 3 & - & 0.1 & 9 \\
\hline Acacia galpinii & Fabaceae & Mokala & - & - & 3 & - & - & 1 & - & - & 0.2 & - & - & 0.4 \\
\hline Combretum albopunctatum & Combretaceae & Motsoketsane & - & - & 20 & - & - & 23 & - & - & 2 & - & - & 7 \\
\hline Gardenia volkensii & Rubiaceae & Morala & - & - & 26 & - & - & 6 & - & - & 1 & - & - & 3 \\
\hline Unidentified species & - & - & - & - & 0.4 & - & - & 1 & - & - & 1 & - & - & 1 \\
\hline Sub-Total & & & 2629 & 4271 & 2745 & & & & & & & & & \\
\hline Total & & & & 9645 & & & & & & & & & & \\
\hline
\end{tabular}

IS = Island Safari Lodge, $\mathrm{SO}=$ Shorobe Village and XO = Xobe Village, IVI = Important Value Index; 0 indicates values very close to 0; and - = absent.

Table 2. Jaccard's coefficient of similarity (\%) in family, genus and species composition among the three study sites.

\begin{tabular}{|c|c|c|c|}
\hline \multirow[t]{2}{*}{ Taxa/Study Site } & \multicolumn{3}{|c|}{ Study Site } \\
\hline & Island Safari & Shorobe & Xobe \\
\hline \multicolumn{4}{|l|}{ Family } \\
\hline Island Safari & - & 72 & 46 \\
\hline Shorobe & & - & 48 \\
\hline Xobe & & & - \\
\hline \multicolumn{4}{|l|}{ Genera } \\
\hline Island Safari & - & 87 & 55 \\
\hline Shorobe & & - & 54 \\
\hline Xobe & & & - \\
\hline \multicolumn{4}{|l|}{ Species } \\
\hline Island Safari & - & 87 & 64 \\
\hline Shorobe & & - & 56 \\
\hline Xobe & & & - \\
\hline
\end{tabular}




\subsection{Density, Frequency and Dominance}

The mean density of all the woody species recorded in the three study sites was 9645 individual ha ${ }^{-1}$ while the mean densities of the woody species encountered in Island Safari, Shorobe and Xobe were 2629, 4271 and 2745 individuals ha ${ }^{-1}$, respectively (Table 1). The mean densities ranged from 1 - 1000, 0.2 - 1676 and 0.2 - 1194 individuals ha ${ }^{-1}$ in Island Safari, Shorobe and Xobe, respectively.

The five densest species were Colophospermum mopane (1000 individuals ha ${ }^{-1}$ ), Dichrostachys cinerea (437 individuals $\mathrm{ha}^{-1}$ ), Acacia tortilis (360 individuals $\mathrm{ha}^{-1}$ ), Philenoptera violacea (182 individuals ha ${ }^{-1}$ ) and Terminalia prunioides (143 individuals $\mathrm{ha}^{-1}$ ) in Island Safari, C. mopane (1676 individuals ha $\left.{ }^{-1}\right)$, A. tortilis (510 individuals ha ${ }^{-1}$ ), Acacia erioloba (417 individuals $\mathrm{ha}^{-1}$ ), P. violacea $\left(257\right.$ individuals ha ${ }^{-1}$ ) and $D$. cinerea (218 individuals ha ${ }^{-1}$ ) in Shorobe and Acacia mellifera (1194 individuals ha ${ }^{-1}$ ), A. tortilis (1068 individuals ha ${ }^{-1}$ ), Philenoptera nelsii (106 individuals ha ${ }^{-1}$ ), Acacia luederitzii (49 individuals ha ${ }^{-1}$ ) and A. erubescens (45 individuals $\mathrm{ha}^{-1}$ ) in Xobe (Table 1). In contrast, Hyphaene petersiana, Mimusops zeyheri, Combretum mossambicense, Capparis tomentosa and Combretum collinum in Island Safari, Acacia fleckii, Terminalia sericea, Garcinia livingstonei, A. erubescens and Euclea divinorum in Shorobe, and Ziziphus mucronata, Acacia nilotica, C. mossambicense, A. fleckii, P. violacea and Grewia bicolor were the species with the lowest densities (Table 1).

In Island Safari, the most frequent woody species were D. cinerea (100\%), A. tortilis (97\%), C. mopane (71\%) and $P$. violacea $(52 \%)$ while the most dominant woody species were $C$. mopane $\left(28 \mathrm{~m}^{2} \cdot \mathrm{ha}^{-1}\right), D$. cinerea $(10$ $\left.\mathrm{m}^{2} \cdot \mathrm{ha}^{-1}\right)$ and A. tortilis $\left(9 \mathrm{~m}^{2} \cdot \mathrm{ha}^{-1}\right)$. The most frequent species in Shorobe were A. erioloba (82\%), A. tortilis (72\%), D. cinerea (59\%) and P. violacea (49\%) while C. mopane $\left(29 \mathrm{~m}^{2} \cdot \mathrm{ha}^{-1}\right)$, A. erioloba $\left(14 \mathrm{~m}^{2} \cdot \mathrm{ha}^{-1}\right)$ and $A$. tortilis $\left(12 \mathrm{~m}^{2} \cdot \mathrm{ha}^{-1}\right)$ were the most dominant species. Acacia mellifera (82\%), A. tortilis (70\%) and P. nelsii (36\%) were the most frequent woody speciesat Xobe while the most dominant woody species were $A$. tortilis $\left(50 \mathrm{~m}^{2} \cdot \mathrm{ha}^{-1}\right)$, A. mellifera $\left(33 \mathrm{~m}^{2} \cdot \mathrm{ha}^{-1}\right)$ and P. nelsii $\left(22 \mathrm{~m}^{2} \cdot \mathrm{ha}^{-1}\right)$ (Table 1$)$.

\subsection{Importance Value Index}

Colophospermum mopane (84), D. cinerea (44), A. tortilis (40), P. violacea (25) and T. prunioides (20) exhibited the highest IVI values in Island Safari, C. mopane (59), A. erioloba (44), A. tortilis (41), P. violacea (25) and C. imberbe (22) had the highest IVI values in Shorobe, and A. mellifera (90), A. tortilis (90), P. nelsii (28) and A. luederitzii (16) showed the highest IVI values in Xobe (Table 1). In contrast, the woody species, which exhibited the lowest IVI values (IVI < 1) were C. mossambicense, C. tomentosa and E. divinorum in Island Safari, 13 different species in Shorobe, and Acacia galpinii, A. nilotica, C. mossambicense and G. bicolor.

\subsection{Population Structure}

The woody species recorded from the three study sites demonstrated diverse patterns of population structures. However, these patterns can be broadly categorized into two major groups, i.e.:

Group I-represents woody species that exhibited stable population structures composed of the highest density of individuals at the lowest DBH class followed by gradually declining densities of individuals with increasing DBH classes (Figure 2(a)). The following species were categorized under this group:

a) A. erioloba, A. hebeclada, A. luederitzii, A. nilotica, A. sieberiana, A. tortilis, C. mopane, Combretum hereroense, Croton megalobotrys, D. cinerea, G. livingstonei, G. bicolor and Z. mucronata in Island Safari (29\% of all the species recorded);

b) A. erioloba, A. tortilis, A. mellifera, C. mopane, Combretum imberbe, D. cinerea, Grewia retinervis and Gymnosporia senegalensis at Shorobe (20\% of all the species); and

c) Combretum albopunctatum, D. cinerea, G. senegalensis and Ximenia americana in Xobe (15\% of all the species).

Group II-represents woody species that exhibited unhealthy population structures resulting from occurrence of individuals only in the lowest DBH classes (seedlings) (Figure 2(b)), only individuals in the first few DBH classes (Figure 2(c)) and seedlings and/or individuals missing in most of the DBH classes (Figure 2(d)). The following species were categorized under this group:

a) A. mellifera, Albizia anthelmintica, A. harveyi, Berchemia discolor, C. tomentosa, C. collinum, C. imberbe, C. mossambicense, Diospyros lycoioides, E. divinorum, Grewia flava, G. retinervis, G. senegalensis, H. petersiana, Mimusops zeyheri, P. violacea, Rhus tenuinervis, T. prunioides, X. americana and Lekwati in Island Safari (61\% of all the species); 
Colophospermum mopane

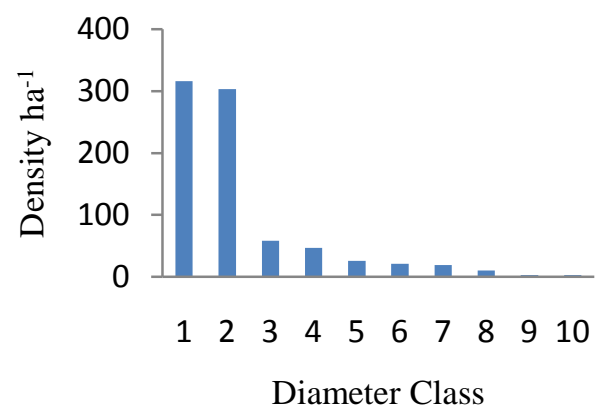

(a)

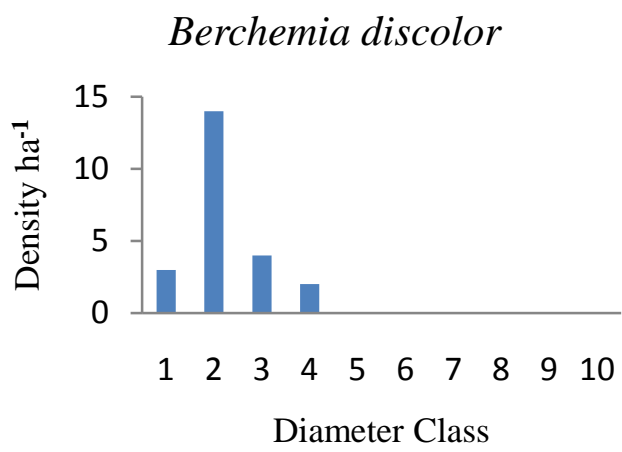

(c)
Philenoptera violacea

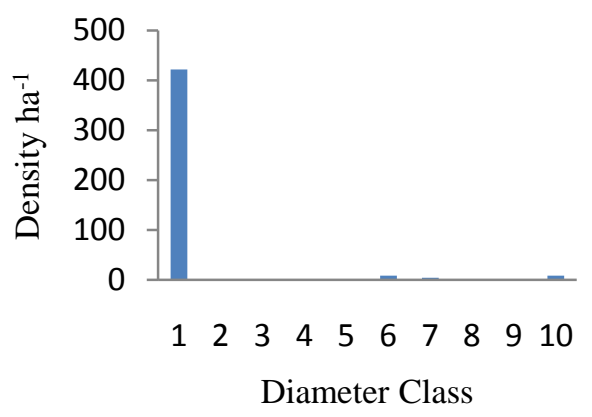

(b)

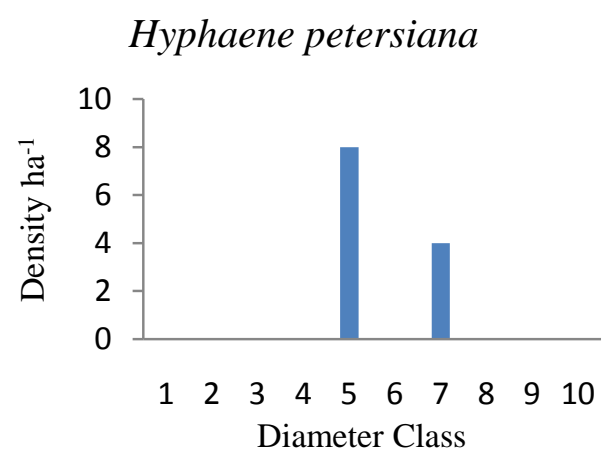

(d)

Figure 2. Population structure of woody species recorded at Island Safari ((a)-(d)), Shorobe and Xobe [diameter class (DBH): $1=<2 \mathrm{~cm} ; 2=2-5 \mathrm{~cm} ; 3=5-10 \mathrm{~cm} ; 4=10-15 \mathrm{~cm} ; 5=15-20 \mathrm{~cm} ; 6=20$ $25 \mathrm{~cm} ; 7=25-30 \mathrm{~cm} ; 8=30-35 ; 9=35-40 ; 10=>40 \mathrm{~cm}]$.

b) A. erubescens, A. fleckii, A. hebeclada, A. nigrescens, A. nilotica, A. sieberiana, A. anthelmintica, A. harveyi, B. discolor, Boscia albitrunca, C. tomentosa, C. collinum, C. hereroense, C. mossambicense, Commiphora mossabicensis, C. megalobotrys, D. lycioides, E. divinorium, G. livingstonei, G. bicolor, G. flava, G. flavescens, H. petersiana, M. zeyheri, P. nelsii, P. violacea, Rhigozum brevispinosum, Rhus tenunervis, T. prunioides, $T$. sericea and $X$. americana, Z. mucronata and Motorokofina (unidentified sp.) in Shorobe (80\% of all the species); and

c) A. erioloba, A. erubescens, A. fleckii, A. galpinii, A. luederitzii, A. mellifera, A. nilotica, A. tortilis, A. anthelmintica, B. albitrunca, C. hereroense, C. mossambicense, C. megalobotrys, Gardenia volkensii, G. bicolor, G. flava, G. retinervis, M. zeyheri, P. nelsii, P. violacea, T. prunioides, Z. mucronata and unidentified species in Xobe ( $85 \%$ of all the species).

\section{Discussion}

Of the three study sites, Shorobe exhibited the highest number of families, genera and species followed by Island Safari and, then, Xobe. Island Safari and Shorobe exhibited similar diversity values, which were more than 1.4 times higher than that recorded in Xobe. Shannon diversity index values observed in the three study sites fall within the range $(0.70$ - 3.57) reported for other dry forests of the Sub-Saharan region (Shackleton, 1993; Obiri et al., 2002; Venter \& Witkowski, 2010). The high diversity of woody plants in Shorobe and Island Safari was probably a result of high species richness and abundance in these study areas. The relatively high diversity at both sites can be attributed to low disturbance, habitat conditions and species characteristics (Zegeye et al., 2006, 2011; Tadele et al., 2014). Typically, this could be the case for Island Safari, which has been exclosed since the early 1980s. However, evenness values of woody species at the three study sites were more or less similar, implying that individuals of the different species recorded exhibited moderately similar abundance at the three sites. The relatively high diversity and evenness indices indicate the need to conserve the floristic diversity of the study sites and also protect the woody vegetation from human disturbances (Zegeye et al., 2011). 
The reasons for variation in floristic composition at the three study sites could be due to excessive anthropogenic disturbances, disparity in conditions for regeneration and exploitation of some species, especially at Xobe (Wassie et al., 2005). Anthropogenic disturbances, such as logging or cutting trees, usually, result in an immediate decline in species diversity (Noble and Dirzo, 1997). Xobe, which is located in the vicinity of Maun (Figure 1), is used as a cattle ranch by not only the local communities but also residents of Maun. It has been exposed not only to overgrazing, as a result, but also exploitation as more areas have and continue to be cleared, especially for molapo and rain-fed agricultural development. On the other hand, Island Safari is a private property with an exclosure to protect it from any exploitation. Human induced disturbances determine the vegetation structure and composition of forests by their influences on the regeneration success of woody species (Cotler and Ortega-Larrocea 2006). The considerable floristic variations (species richness, genera, families and overall diversity) between the two open sites (Shorobe and Xobe), were probably due to their differences in the soil types and moisture availability (Chimbari et al., 2009; Neelo et al., 2013).

Shorobe exhibited much higher density (4271 individuals ha ${ }^{-1}$ ) of woody species than both Island Safari (2629 individuals ha ${ }^{-1}$ ) and Xobe (2745 individuals ha ${ }^{-1}$ ), which had more or less similar densities. The highest density of woody species at Shorobe can be linked to the higher number of species recorded at this site than at the other two sites. Also, Shorobe is adjacent to Moremi Game Reserve (MGR), which has a potential to serve as a seed donor to the adjacent vegetation at Shorobe. Seeds of woody species can be dispersed by wild animals inhabiting the MGR, water from the Okavango Delta and wind, increasing the chances of seed germination, seedling recruitment, growth and, ultimately, species richness and diversity of the woody species. Island Safari and Shorobe had the same densest top four woody species, namely C. mopane, A. tortilis, P. violacea and $D$. cinerea, which could be attributed to their close proximity to each other, suggesting similar edaphic conditions. Surprisingly, the densest woody species in Island Safari and Shorobe, i.e. C. mopane, was not recorded in any of the quadrats assessed in Xobe, which could be attributed to differences in the edaphic conditions between Xobe and the other two sites (Chimbari et al., 2010; Neelo et al., 2013).

Acacia mellifera and A. tortilis had much higher densities at Xobe than Island Safari and Shorobe with more than $82 \%$ of the total density recorded at Xobe. More than $83 \%$ of the total density in Xobe was represented by the three Acacia species, two of which are also among the most dominant and frequently found with the highest IVI values. This might suggest signs of bush encroachment due to overgrazing and over-exploitation of woody species at Xobe (DEA, 2008; Neelo et al., 2013). Acacia mellifera is known to form impenetrable patches of thickets at Xobe, and also it encroaches eroded sites (Ellery \& Ellery, 1997) and heavily grazed areas (El-Sheikh, 2013). Acacia tortilis is also a common and widespread species in Botswana, which occurs on clay or loam soils in a variety of woodlands, generally near floodplains and pans. It encroaches heavily grazed sites (Ellery \& Ellery, 1997; Neelo et al., 2013). The domination of Acacia species, which are indicative of heavy grazing and encroachment, at Xobe is consistent with the fact that Xobe is used as a cattle post by people living in the nearby Maun Town. Also, the relatively high number and density of Acacia species recorded at Xobe may be associated with their seed dispersal, which is known to be facilitated by ruminants that usually browse them, and the subsequent conducive environment for seed germination and seedling development within the accompanying organic manure from animal droppings (Teketay 1996, 1997a, 2005a; Kalema, 2010; Neelo et al., 2013). The variation in the density and frequency among woody species was probably a result of the differences in site conditions, species characteristics, economic importance of species and anthropogenic disturbances (Shibru and Balcha, 2004; Tesfaye and Teketay, 2005; Hundera and Gadissa, 2008).

Importance Value Index is an important parameter that indicates the ecological significance of species in a given ecosystem (Zegeye et al., 2006; Senbeta and Teketay, 2003; Worku et al., 2012). Species with high IVI values are regarded as more important than those with low IVI values (Zegeye et al., 2011). The IVI values are also used in conservation programmes, where species with low IVI values are prioritized for conservation (Shibru 2002; Shibru and Balcha 2004) and those with high IVI values need monitoring management (Gurmessa et al. 2012). Acacia tortilis, C. mopane, A. erioloba, D. cinerea and P. nelsii at Island Safari, C. mopane, A. erioloba, A. tortilis, P. violacea, and C. imberbe at Shorobe and A. tortilis, A. mellifera and P. nelsii at Xobe can be considered the most ecologically important woody species with IVI values of more than 20 contributed by their high values of density, frequency and dominance. Interestingly, $A$. tortilis is recorded among the most ecologically important woody species at all the three study sites. Acacia tortilis and A. mellifera can be regarded as the most ecologically important woody species at Xobe (both with the same IVI value of 90) than any other species at the other two sites. Species with the same IVI have the same or similar population structure (Lamprecht, 1989). 
Tree size class distribution is an important indicator of changes in population structure and species composition of a forest ecosystem (Newbery \& Gartlan, 1996; Condit et al., 1998). Population structure of woody species yields information on the history of past disturbance of this species and its environment (Teketay, 1997b; Wale et al., 2012), which can be used to predict the future trend of the population of a particular species (Teketay, 1997b; Wilson \& Witkowski, 2003; Kalema, 2010). Based on the assessment of diameter class distributions, the population structure patterns of the woody species recorded from Island Safari, Shorobe and Xobe were categorized into two groups. In the first group, the number of individuals decreased with the increasing diameter class, resulting in an inverted J-shaped population, an indication of stable population structure or healthy regeneration status (Teketay 1997a; Alelign et al., 2007; Tesfaye et al., 2010; Zegeye et al., 2011; Helm \& Witkowski, 2012; El-Sheikh, 2013). This pattern was exhibited by about 29\%, 20\% and 15\% of the woody species recorded at Island Safari, Shorobe and Xobe, respectively. Typical examples are A. erioloba, C. mopane and C. hereroense at Island Safari, A. tortilis, D. cinerea and G. senegalensis at Shorobe and C. albopunctatum, D. cinerea and $X$. americana at Xobe. Island Safari exhibited the highest number of species in this group than Shorobe and Xobe, indicating the contribution of the exclosure in protecting the woody species from disturbance and exploitation. Similar to other studies on dry forests in Africa (Teketay, 1997, 2005a, 2005b; Mwavu \& Witkowski, 2009), population structure of woody species in undisturbed forests showed an inverted J-shaped curve pattern.

On the contrary, it was alarming to find out that $71 \%, 80 \%$ and $85 \%$ of the woody species recorded in Island Safari, Shorobe and Xobe, respectively, exhibited hampered regeneration and, thus, unhealthy population structures. In open sites, human disturbance, particularly grazing, is usually the major reason for hampered or poor regeneration (Zegeye et al., 2011). High browsing pressure can lead to the absence of seedlings or juveniles as a result of high seedling mortality (Tremblay et al., 2007; Negussie et al., 2008). Although Island Safari has been exclosed for more than 30 years, the fate of many of the woody species is the same as the other two sites in terms of the hampered regeneration. This can be attributed to the heavy over-grazing and cutting of trees that took place before the establishment of the exclosure as well as the annual flooding of most of the area covered by the woody vegetation caused by the overflow of the adjacent Thamalakane River. The death of seedlings and, even, bigger trees, such as Acacia species, is caused by the recurrent flooding, which leads to water logging of the area covered by the woody vegetation resulting in the decline of the species richness, density, frequency, dominance and, hence, IVI as well as hampered regeneration and unstable population structure of the woody species. Therefore, there is an urgent need to address the unhealthy population structures of the woody species through investigation of the major causes of the prevalent hampered regeneration, and also designing measures that will facilitate natural and artificial regeneration of these species at the three study sites.

\section{Acknowledgements}

Authors are grateful to the International Development Research Centre (IDRC) for providing financial support for this study through the Botswana Eco Health Project. We are thankful to Kgosi (Chiefs), Village Development Committees and local communities of the study sites, field technicians and Transport Section of the Okavango Research Institute (ORI), University of Botswana, community research assistants and Peter Smith University of Botswana Herbarium (PSUB). We would also like to thank ORI and its management for the logistical support and an anonymous reviewer for the valuable comments on an earlier version of the manuscript.

\section{References}

Aerts, R., Nyssen, J., \& Haile, M. (2009). On the Difference between “Exclosures” and “Enclosures” in Ecology and the Environment. Journal of Arid Environments, 73, 762-763. http://dx.doi.org/10.1016/j.jaridenv.2009.01.006

Alelign, A., Teketay, D., Yemshaw, Y., \& Edwards, S. (2007). Diversity and Status of Regeneration of Woody Plants on the Peninsula of Zegie, Northwestern Ethiopia. Tropical Ecology, 48, 37-49.

Birhane, E., Teketay, D., \& Barklund, P. (2004). Enclosures as a Tool of Rehabilitating Degraded Woodlands in Ethiopia. In: D. Blay, E. Bonkoungou, S. A. O. Chamshama, \& B. Chikamai (Eds.), Rehabilitation of Degraded Lands in Sub-Saharan Africa (pp. 73-77). Neulengbach: Forestry Research Network for Sub-Saharan Africa and IUFRO Special Program for Developing Countries.

Birhane, E., Teketay, D., \& Barklund, P. (2006). Actual and Potential Contribution of Exclosures to Enhance Biodiversity of Woody Species in the Drylands of Eastern Tigray. Journal of Drylands, 1, 134-147. 
CSO (Central Statistics Office) (2011). Botswana Population and Housing Census. Gaborone: Central Statistics Office.

Chimbari, M. J., Magole, L., Wiles, G., Dikgola, K., Kurugundla, N., Teketay, D., Ngwenya, B., Nyepi, M. S., Motsumi, S., Ama, K., Thakadu, O., \& Chombo, O. (2009). Application of the Ecohealth Approach to Understand Flood-Recession (Molapo) Farming in the Context of Hydro-Climate Variability and Hydro-Climate Change in the Okavango Delta, Botswana. Maun: University of Botswana, Harry Oppenheimer Okavango Research Centre.

Condit, R., Sukumar, R., Hubbell, S. P., \& Foster, R. B. (1998). Predicting Population Trends from Size Distributions: A Direct Test in a Tropical Tree Community. American Naturalist, 152, 495-509. http://dx.doi.org/10.1086/286186

Congdon, R. A., \& Herbohn, J. L. (1993). Ecosystem Dynamics of Disturbed and Undisturbed Sites in North Queensland Wet Tropicalrain Forest. I. Floristic Composition, Climate and Soil Chemistry. Journal of Tropical Ecology, 9, 349-363. http://dx.doi.org/10.1017/S0266467400007409

Cotler, H., \& Ortega-Larrocea, M. P. (2006). Effects of Land Use on Soil Erosion in a Tropical Dry Forest Ecosystem, Chamela Watershed, Mexico. Catena, 65, 107-117. http://dx.doi.org/10.1016/j.catena.2005.11.004

DEA (2008). Okavango Delta Management Plan. Gaborone: Department of Environmental Affairs (DEA).

Ellery, K., \& Ellery, W. (1997). Plants of the Okavango Delta: A Field Guide. Durban: Tsaro Publisher.

Elliot, S., Blakesley, D., \& Hardwick, K. (2013). Restoring Tropical Forests: A Practical Guide. Kew: Royal Botanic Gardens.

El-Sheikh, M. A. (2013). Population Structure of Woody Plants in the Arid Cloud Forests of Dhofar, Southern Oman. Acta Botanica Croatica, 72, 97-111. http://dx.doi.org/10.2478/v10184-012-0008-6

Fairhead, J., \& Leach, M. (1998). Reframing Deforestation: Global Analysis and Local Realities: Studies in West Africa. London: Routledge.

GEMS (1988). Inventory and Monitoring of Sahelian Pastoral Ecosystems. Woody Vegetation in the Sahel. Nairobi: Gems Sahel Series 4, UNEP, FAO, Government Senegal.

Gurmessa, F., Soromessa, T., \& Kelbessa, E. (2012). Structure and Regeneration Status of Komoto Afromontane Moist Forest, East Wollega Zone, West Ethiopia. Journal of Forestry Research, 23, 205-216. http://dx.doi.org/10.1007/s11676-012-0242-8

Hailu, M., Oba, G., Angassu, A., \& Weladji, R. B. (2006). The Role of Area Enclosures and Fallow Age in the Restoration of Plant Diversity in Northern Ethiopia. African Journal of Ecology, 44, 507-514. http://dx.doi.org/10.1111/j.1365-2028.2006.00664.x

Hall, P., \& Bawa, K. (1993). Methods to Assess the Impacts of Extraction of Non-Timber Tropical Forest Products on Plant Populations. Economic Botany, 47, 234-247. http://dx.doi.org/10.1007/BF02862289

Heath, A., \& Heath, R. (2010). Field Guide to the Plants of Northern Botswana: Including the Okavango Delta. Kew: Kew Publishing, Royal Botanic Gardens.

Helm, C. V., \& Witkowski, E. T. F. (2012). Characterising Wide Spatial Variation in Population Size Structure of a Keystone African Savanna Tree. Forest Ecology and Management, 263, 175-188. http://dx.doi.org/10.1016/j.foreco.2011.09.024

Holmes, C. M. (2003). Assessing the Perceived Utility of Wood Resources in a Protected Area of Western Tanzania. Biological Conservation, 111, 179-189. http://dx.doi.org/10.1016/S0006-3207(02)00272-0

Hundera, K., \& Gadissa, T. (2008). Vegetation Composition and Structure of Belete Forest, Jimma Zone, Southwestern Ethiopia. Ethiopian Journal of Biological Sciences, 7, 1-15.

Kalema, V. N. (2010). Diversity, Use and Resilience of Woody Plants in a Multiple Land-Use Equatorial African Savanna, Uganda. Ph.D. Thesis, Johannesburg: University of the Witwatersrand.

Kent, M., \& Coker, P. (1992). Vegetation Description and Analysis: A Practical Approach. England: John Wiley and Sons Ltd.

Krebs, C. J. (1989). Ecological Methodology. New York: Harper Collins Publishers.

LaFrankie, J. V., Ashton, P. S., Chuyong, G. B., Co, L., Condit, R., Davies, S. J., Foster, R., Hubbell, S. P., Kenfack, D., Lagunzad, D., Losos, E. C., Md. Noor, N. S., Tan, S., Thomas, D. W., Valencia, R., \& Villa, G. (2006). Contrasting Structure and Composition of the Understory in Species-Rich Tropical Rain Forests. Ecology, 87, 2298-2305. http://dx.doi.org/10.1890/0012-9658(2006)87[2298:CSACOT]2.0.CO;2

Lamprecht, H. (1989). Silviculture in the Tropics: Tropical Forest Ecosystems and Their Tree Species-Possibilities and Methods for Their Long-Term Utilization. Eschborn: Deutshe Gesellschaftfü Technische Zusammenarbeit (GTZ) GmbH.

Lawes, M. J., Joubert, R., Griffiths, M. E., Boudreau, S., \& Chapman, C. A. (2007). The Effect of the Spatial Scale of Recruitment on Tree Diversity in Afromontane Forest Fragments. Biological Conservation, 139, 447-456. http://dx.doi.org/10.1016/j.biocon.2007.07.016

Lu, X. T., Yin, J. X., \& Tang, J. W. (2010). Structure, Tree Species Diversity and Composition of Tropical Rainforests in Xishuangbanna, South West China. Journal of Tropical Forest Science, 22, 260-270. 
Magurran, A. E. (2004). Measuring Biological Diversity. Malden and Oxford: Blackwell Publishing.

McCarthy, T. S., Bloem, A., \& Larkin, P. A. (1998). Observations on the Hydrology and Geohydrology of the Okavango Delta, Botswana. Journal of Geology, 101, 101-117.

Mekuria, W., Veldkamp, E., Haile, M., Nyssen, J., Muys, B., \& Gebrehiwot, K. (2007). Effectiveness of Exclosures to Restore Degraded Soils as a Result of Overgrazing in Tigray, Ethiopia. Journal of Arid Environments, 69, 270-284. http://dx.doi.org/10.1016/j.jaridenv.2006.10.009

Mengistu, T., Teketay, D., Hulten, H., \& Yemshaw, Y. (2005a). The Role of Enclosures in the Recovery of Woody Vegetation in Degraded Dryland Hillsides of Central and Northern Ethiopia. Journal of Arid Environments, 60, 259-281. http://dx.doi.org/10.1016/j.jaridenv.2004.03.014

Mengistu, T., Teketay, D., Hulten, H., \& Yemshaw, Y. (2005b). The Role of Communities in Closed Area Management in Ethiopia. Mountain Research and Development, 25, 44-50. http://dx.doi.org/10.1659/0276-4741(2005)025[0044:TROCIC]2.0.CO;2

Mwavu, N. E., \& Witkowski, E. T. F. (2009). Seedling Regeneration, Environment and Management in a Semi-Deciduous African Tropical Rain Forest. Journal of Vegetation Science, 20, 791-804. http://dx.doi.org/10.1111/j.1654-1103.2009.01084.x

Neelo, J., Teketay, D., Masamba, W., \& Kashe, K. (2013). Diversity, Population Structure and Regeneration Status of Woody Species in Dry Woodlands Adjacent to Molapo Farms in Northern Botswana. Open Journal of Forestry, 3, 138-151. http://dx.doi.org/10.4236/ojf.2013.34022

Negussie, A., Aerts, R., Gebrehiwot, K., \& Muys, B. (2008). Seedling Mortality Causes Recruitment Limitation of Boswellia Papyrifera in Northern Ethiopia. Journal of Arid Environments, 72, 378-383. http://dx.doi.org/10.1016/j.jaridenv.2007.06.009

Newbery, D. M. C., \& Gartlan, J. S. (1996). A Structural Analysis of Rain Forest at Korup and Douala-Edea, Cameroon. Proceedings of the Royal Society of Edinburgh, 104B, 107-124.

Noble, I. R., \& Dirzo, R. (1997). Forests as Human-Dominated Ecosystems. Science, 277, 522-525. http://dx.doi.org/10.1126/science.277.5325.522

Obiri, J., Lawes, M., \& Mukolwe, M. (2002). The Dynamics and Sustainable Use of High-Value Tree Species of the Coastal Pondoland Forests of the Eastern Cape Province, South Africa. Forest Ecology and Management, 166, 131-148. http://dx.doi.org/10.1016/S0378-1127(01)00665-X

Peters, C. M. (1996). The Ecology and Management of Non-Timber Forest Resources. World Bank Technical Paper 322, Washington: World Bank.

Pickett, S. T. A., \& White, P. S. (1985). The Ecology of Natural Disturbance and Patch Dynamics. Orlando, FL: Academic Press.

Roodt, V. (1993). The Shell Field Guide to the Common Trees of the Okavango Delta and Moremi Game Reserve. Gaborone: Shell Oil (Pty) Ltd.

Roodt, V. (1998). Trees and Shrubs of the Okavango Delta. Gaborone: Shell Oil Botswana (Pty) Ltd.

Sapkota, I. P., Tigabu, M., \& Oden, P. C. (2009). Spatial Distribution, Advanced Regeneration and Stand Structure of Nepalese Sal (Shorea robusta) Forest Subject to Disturbances of Different Intensities. Forest Ecology and Management, 257, 1966-1975. http://dx.doi.org/10.1016/j.foreco.2009.02.008

Senbeta, F., \& Teketay, D. (2003). Diversity, Community Types and Population Structure of Woody Plants in Kimphee Forest, a Unique Nature Reserve in Southern Ethiopia. Ethiopian Journal of Biological Sciences, 2, 169-187.

Setshogo, M. P. (2002). Common Names of Some Flowering Plants of Botswana. Rome: FAO.

Setshogo, M. P. (2005). Preliminary Checklist of the Plants of Botswana. Pretoria: Southern African Botanical Diversity Network (SABONET).

Setshogo, M. P., \& Venter, F. (2003). Trees of Botswana: Names and Distribution. Pretoria: Southern African Botanical Diversity Network (SABONET).

Shackleton, C. M. (1993). Demography and Dynamics of the Dominant Woody Species in a Communal and Protected Area of the Eastern Transvaal Lowveld. South African Journal of Botany, 59, 569-574.

Sheil, D. (1999). Tropical Forest Diversity, Environmental Change and Species Augmentation: After the Intermediate Disturbance Hypothesis. Journal of Vegetation Science, 10, 851-860. http://dx.doi.org/10.2307/3237310

Shibru, S. (2002). Inventory of Woody Species in Dindin Forest. Technical Report No. 01, Addis Ababa: IBCR/GTZ/FGRCP.

Shibru, S., \& Balcha, G. (2004). Composition, Structure and Regeneration Status of Woody Species in Dindin Natural Forest. Ethiopian Journal of Biological Sciences, 3, 15-35.

Singh, J. S., \& Singh, S. P. (1992). Forests of Himalaya: Structure, Functioning and Impact of Man. Nainital: GyanodayaPrakashan. 
Ssegawa, P., \& Nkuutu, D. N. (2006). Diversity of Vascular Plants on Ssese Islands in Lake Victoria, Central Uganda. African Journal of Ecology, 44, 22-29. http://dx.doi.org/10.1111/j.1365-2028.2006.00609.x

Tadele, D., Lulekal, E., Damtie, D., \& Assefa, A. (2014). Floristic Diversity and Regeneration Status of Woody Plants in Zengena Forest, a Remnant Montane Forest Patch in Northwestern Ethiopia. Journal of Forestry Research, 25, 329-336. http://dx.doi.org/10.1007/s11676-013-0420-3

Teketay, D. (1996). Germination Ecology of Twelve Indigenous and Eight Exotic Multipurpose Leguminous Species from Ethiopia. Forest Ecology and Management, 80, 209-223. http://dx.doi.org/10.1016/0378-1127(95)03616-4

Teketay, D. (1997a). Germination Ecology of Acacia negrii, an Endemic Multipurpose Tree from Ethiopia. Tropical Ecology, 38, 39-46.

Teketay, D. (1997b). Seedling Populations and Regeneration of Woody Species in Dry Afromontane Forests of Ethiopia. Forest Ecology and Management, 98, 149-165. http://dx.doi.org/10.1016/S0378-1127(97)00078-9

Teketay, D. (2005a). Seed and Regeneration Ecology in Dry Afromontane Forests of Ethiopia: I. Seed Production-Population Structures. Tropical Ecology, 46, 29-44.

Teketay, D. (2005b). Seed and Regeneration Ecology in Dry Afromontane Forests of Ethiopia: II. Forest Disturbance and Succession. Tropical Ecology, 46, 45-64.

Teketay, D., Lemenih, M., Bekele, T., Yemshaw, Y., Feleke, S., Tadesse, W., Moges, Y., Hunde, T., \& Nigussie, D. (2010). Forest Resources and Challenges of Sustainable Forest Management and Conservation in Ethiopia. In F. Bongers, \& T. Tennigkeit (Eds.), Degraded Forests in Eastern Africa: Management and Restoration (pp. 19-63). London: Earthscan.

Tesfaye, G., \& Teketay, D. (2005). The Influence of Logging on Natural Regeneration of Woody Species in Harenna Montane Forest, Ethiopia. Ethiopian Journal of Biological Sciences, 4, 59-73.

Tesfaye, G., Teketay, D., Fetene, M., \& Beck, E. (2010). Regeneration of Seven Indigenous Tree Species in a Dry Afromontane Forest, Southern Ethiopia. Flora, 205, 135-143. http://dx.doi.org/10.1016/j.flora.2008.12.006

Tilman, D. (1988). Plant Strategies and the Dynamics and Structure of Plant Communities. Princeton, NJ: Princeton University Press.

Timberlake, J. (1980). Handbook of Botswana Acacias. Gaborone: Ministry of Agriculture.

Tremblay, J. P., Huot, J., \& Potvin, F. (2007). Density-Related Effects of Deer Browsing on the Regeneration Dynamics of Boreal Forests. Journal of Applied Ecology, 44, 552-562. http://dx.doi.org/10.1111/j.1365-2664.2007.01290.x

van Wyk, B., \& van Wyk, P. (1997). Field Guide to Trees of Southern Africa. Cape Town: Struik Nature.

van Wyk, B., \& van Wyk, P. (2007). How to Identify Trees in Southern Africa. Cape Town: Struik Nature.

Venkateswaran, R., \& Parthasarathy, N. (2003). Tropical Dry Evergreen Forests on the Coromandel Coast of India: Structure, Composition and Human Disturbance. Ecotropica, 9, 45-58.

Venter, S. M., \& Witkowski, E. T. F. (2010). Baobab (Adansonia digitata L.) Density, Size-Class Distribution and Population Trends between Four Land-Use Types in Northern Venda, South Africa. Forest Ecology and Management, 259, 294300. http://dx.doi.org/10.1016/j.foreco.2009.10.016

Vetaas, O. R. (1997). Spatial and Temporal Vegetation Changes along a Moisture Gradient in Northeastern Sudan. Biotropica, 25, 164-175. http://dx.doi.org/10.2307/2389180

von Maydell, H. J. (1986). Trees and Shrubs of the Sahel: Their Characteristics and Uses. Eschborn: GTZ.

von Maydell, H. J. (1995). Appraisal of Practices to Manage Woody Plants in Semi-Arid Environments. In S. Bruns, J. Furberg, O. Luukkanen, \& P. Wood (Eds.), Dryland Forestry Research (pp. 15-30). Hyytiälä: Proc. IFS/IUFRO Workshop.

Wale, H. A., Bekele, T., \& Dalle, G. (2012). Floristic Diversity, Regeneration Status and Vegetation Structure of Woodlands in Metema Area, Amhara National Regional State, Northwestern Ethiopia. Journal of Forestry Research, 23, 391-398. http://dx.doi.org/10.1007/s11676-012-0275-z

Wassie, A., Teketay, D., \& Powell, N. (2005). Church Forests in North Gonder Administrative Zone, Northern Ethiopia. Forests, Trees and Livelihoods, 15, 349-373. http://dx.doi.org/10.1080/14728028.2005.9752536

Wilson, B. G., \& Witkowski, E. T. F. (2003). Seed Banks, Bark Thickness and Change in Age and Size Structure (19971999) of the African Savanna Tree, Burkea africana. Plant Ecology, 167, 151-162. http://dx.doi.org/10.1023/A:1023999806577

Worku, A., Teketay, D., Lemenih, M., \& Fetene, M. (2012). Diversity Regeneration Status and Population Structure of Gum and Resin Producing Woody Species in Borana, Southern Ethiopia. Forests, Trees and Livelihoods, iFirst Article, 1-12.

WCMC (World Conservation Monitoring Center) (1992). Global Biodiversity: Status of the Earth's Living Resources. London: Chapman \& Hall.

Wright, S. J., \& Muller-Landau, H. C. (2006). The Future of Tropical Forest Species. Biotropica, 38, 287-301. http://dx.doi.org/10.1111/j.1744-7429.2006.00154.x 
Zegeye, H., Teketay, D., \& Kelbessa, E. (2006). Diversity, Regeneration Status and Socio-Economic Importance of the Vegetation in the Islands of Lake Ziway, South-Central Ethiopia. Flora, 201, 483-498.

http://dx.doi.org/10.1016/j.flora.2005.10.006

Zegeye, H., Teketay, D., \& Kelbessa, E. (2011). Diversity and Regeneration Status of Woody Species in Tara Gedam and Abebaye Forests, Northwestern Ethiopia. Journal of Forestry Research, 22, 315-328. http://dx.doi.org/10.1007/s11676-011-0176-6 